\title{
INTERNATIONAL JOURNAL OF CURRENT RESEARCH IN CHEMISTRY AND PHARMACEUTICAL SCIENCES
}

(p-ISSN: 2348-5213: e-ISSN: 2348-5221)

www.ijcrcps.com

DOI: $10.22192 / \mathrm{ijcrcps}$

Coden: IJCROO(USA)

Volume 6, Issue 10 - 2019

Research Article

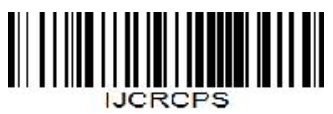

DOI: http://dx.doi.org/10.22192/ijcrcps.2019.06.10.002

\section{Differential Pulse Polarographic Determination of Clopidogrel Bisulphate in Pure and Pharmaceutical Dosage Forms Using Dropping Mercury Electrode}

\author{
Abdul Aziz Ramadan ${ }^{1 *}$, Hasna Mandil ${ }^{2}$, Nidal Ashram \\ Department of Chemistry, Faculty of Science, University of Aleppo, Syria. \\ *1E-mail: dramadan@scs-net.org or dramadan1946@gmail.com; \\ 2E-mail: promandil955@gmail.com
}

\begin{abstract}
Differential pulse polarographic analysis (DPPA) of Clopidogrel Bisulphate (CLPB) in pure and pharmaceutical dosage forms using drop mercury electrode (DME) has been studied. Various parameters (electrolyte, $\mathrm{pH}$, pulse time, pulse amplitude, etc.) affecting on the CLPB determination were examined. The best definition of the analytical signals was found in sodium acetate $0.02 \mathrm{M}$ buffer at $\mathrm{pH}$ 8.0. Under the optimum conditions, liner calibration graph, $\mathrm{I}_{\mathrm{p}}=\mathrm{f}\left(\mathrm{C}_{\mathrm{CLP}}\right)$, was obtained in the concentration ranges of $5 \times 10^{-7} \mathrm{M}$ to $3 \times 10^{-5} \mathrm{M}\left(0.1609\right.$ to $9.6546 \mathrm{~g} \cdot \mathrm{mL}^{-1}$ of CLP), at -1275 to $-1310 \mathrm{mV}$ (versus $\mathrm{Ag} / \mathrm{AgCl}$ ) with percent relative standard deviations (RSD\%) did not exceed $2.9 \%$ for the concentrations 0.1609 g.mL ${ }^{-1}$ of CLP. Regression analysis showed a good correlation coefficient $\left(R^{2}=0.9997\right)$ between $I_{p}$ and concentration over the mentioned range. The limit of detection (LOD) and the limit of quantification (LOQ) were to be 0.0160 and $0.0485 \mu \mathrm{g} \cdot \mathrm{mL}^{-1}$, respectively. The proposed method was validated for linearity, precision and accuracy (LOD and LOQ), repeatability, sensitivity, robustness and specificity. The developed method is applicable for the determination of CLP in pure and different dosage forms in presence of aspirin with average recovery of 99.9 to $101.8 \%$ and the results are in good agreement with those obtained by the HPLC reference method.
\end{abstract}

Keywords: Differential pulse polarographic analysis; Clopidogrel.

Introduction

Clopidogrel bisulphate (CLPB), methyl(+)-(s)- $\alpha$-(ochlorophenyl)6,7-dihydrothieno (3, 2-c) pyridine-5(4H)- acetate bisulphate, is a new antiplatelet agent, and it is similar to ticlopidine in chemical structure (see scheme 1), its molecular weight of $419.8 \mathrm{~g} / \mathrm{mol}$ of CLPB (draw CLP is $321.8 \mathrm{~g} / \mathrm{mol}$ ) [1,2].<smiles>COC(=O)[C@H](c1ccccc1Cl)N1CCc2sccc2C1</smiles>

Scheme 1 Chemical structure of clopidogrel bisulphate (CLPB) 
Int. J. Curr. Res. Chem. Pharm. Sci. (2019). 6(10): 10-19

Clopidogrel is as a potent anti-platelet aggregation agent, has become available in the market. The medical properties, pharmacodynamics, pharmacokinetics and various aspects of this compound have been published [3-5].

The literatures for the quantification of clopidogrel were including potentiometric method $[6,7]$ and voltammetry [8-11], spectrophotometry [12,13], and high performance liquid chromatography $[14,15]$.

The prepared electrode $\mathrm{Bi}_{2} \mathrm{O}_{3}$-poly $p$-aminophenol on glass carbon electrode $\left(\mathrm{Bi}_{2} \mathrm{O}_{3}-\mathrm{Pp}-\mathrm{AP} / \mathrm{GCE}\right)$ was used for determination of clopidogrel in pharmaceutical productions by differential pulse voltammetry and there is a good linear relationship between concentrations of clopidogrel (CLP) in the range of $3 \times 10^{-6}-1 \times 10^{-3} \mathrm{M}$ and obtained areas of voltammograms [8].

The oxidation of CLP at multi-walled carbon nanotube/polyorthoaminophenol modified graphite electrode (MWCNT/POAP/GE) electrode has been performed in sulfuric acid ( $\mathrm{pH} 3.7)$. Cyclic voltammetry (CV), chronoamperometry (CA) under different conditions of $\mathrm{pH}$, scan rates and concentration of CLP were investigated for the determination of CLP using electrochemical techniques [9].

The determination of clopidogrel, an antiplatelet agent, was performed at a gold electrode in $\mathrm{pH} 3.7$ acetate buffer using cyclic voltammetry (CV) and square wave voltammetry (SWV). Each voltammogram was characterized by the well defined peak at approximately $1.0 \mathrm{~V}$. The current of anodic stripping peak exhibited a linear dependence on the clopidogrel concentration in the range from 317.89 to 935.16 $\mu \mathrm{g} \cdot \mathrm{mL}^{-1}[10]$. The voltammetric behavior of clopidogrel bisulfate (CLPB), an antiplatelet agent, was investigated for the first time in the literature on a cathodically pretreated boron-doped diamond electrode (CP-BDDE) using cyclic and square-wave voltammetry [11].

In the present work, electrochemical behavior and differential pulse polarographic analysis of clopidogrel in pure and pharmaceutical dosage forms using dropping mercury electrode was applied.

\section{Experimental}

\section{Reagents}

Working reference standard of clopidogrel bisulphate $(98.5 \%)$ was supplied by D.K. Pharmachem Pvt. Ltd INDIA, (Mfg.11-2018, Exp. 11-2021). Lithium perchlorate trihydrate, di-sodium hydrogen phosphate dodecahydrate, sodium acetate trihydrate, sodium hydroxid, perchloric acid (70\%), ortho-phosphoric acid

() 2019, IJCRCPS. All Rights Reserved
$(85 \%)$, acetic acid $(100 \%)$, boric acid $(100 \%)$ were of GR for analysis purchased from MERCK. Ultrapure mercury from Metrohm Company was used throughout the experiments.

\section{Instruments and apparatus}

A Metrohm 746 VA processor, a Metrohm 747 VA stand with a mercury drop electrode (DME) as a working electrode, an auxiliary platinum electrode and a reference electrode, double junction type, $(\mathrm{Ag} / \mathrm{AgCl})$ saturated with a $3.0 \mathrm{M} \mathrm{KCl}$ solution and the threeelectrode cell were used. All measurements were done at room temperature $25 \pm 5{ }^{\circ} \mathrm{C}$. Highly pure nitrogen gas (99.999\%) was used for de-oxygenation. $\mathrm{pH}$ meter from Radiometer company model ion check was used. The diluter pipette model DIP-1 (Shimadzu), having $100 \mathrm{~L}$ sample syringe and five continuously adjustable pipettes covering a volume range from 10 to $5000 \mathrm{~L}$ (model PIPTMAN $\mathrm{P}$, GILSON), were used for preparation of the experimental solutions. An ultrasonic processor model Powersonic 405 was used to sonicate the sample solutions. Electronic balance (Sartorius-2474; $d=0.01$ $\mathrm{mg}$ ) was used.

\section{Preparation of supporting electrolyte}

Sodium acetate-acetic acid (HAc-NaAc), Britton Robinson, $\mathrm{H}_{3} \mathrm{PO}_{4}-\mathrm{Na}_{2} \mathrm{HPO}_{4}$, lithium perchlorate buffers at concentration $0.100 \mathrm{~mol}^{-1}$ at $\mathrm{pH}(6.0-10.0)$ were used.

\section{A stock standard solution of clopidogrel bisulphate}

This solution was prepared by dissolving $42.63 \mathrm{mg}$ from clopidogrel bisulphate (CLPB) in methanol 100 $\mathrm{mL}\left(1 \times 10^{-3} \mathrm{~mol}^{-1} \mathrm{~L}^{-1}\right)$, then dilute $10.000 \mathrm{~mL}$ from this solution to $100 \mathrm{~mL} \quad\left(1 \times 10^{-4} \mathrm{~mol} . \mathrm{L}^{-1}\right)$.

\section{Working solutions}

The stock solutions were further diluted to obtain working solutions daily just before use in the ranges of clopidogrel: $0.2100,0.4200,0.8400,1.6796,2.5194$, $3.3592,5.0388,6.7184,8.3980,10.4975$ and 12.5970 g. $\mathrm{mL}^{-1}$ of CLPB (equivalent $0.1609,0.3218,0.6436$, $1.2873,1.9309,2.5746,3.8618,5.1491,6.4360$, 8.0460 and 9.6545 of CLP $\mu \mathrm{g} \cdot \mathrm{mL}^{-1}$ ) or $0.500,1.000$, $2.000,4.000,6.000,8.000,12.00,16.00,20.00,25.00$ and 30.00 mol. $\mathrm{L}^{-1}$ by using of the volumes: 0.125 , $0.250,0.500,1.000,1.500,2.000,3.000,4.000,5.000$, 6.250 , and $7.500 \mathrm{~mL}$ from stock standard solutions $\left(1 \times 10^{-4} \mathrm{~mol}^{-\mathrm{L}^{-1}}\right)$ were transferred into $25 \mathrm{~mL}$ volumetric flask. $5.0 \mathrm{~mL}$ of supporting electrolyte was added, and diluted with double distilled water to the mark. 
Int. J. Curr. Res. Chem. Pharm. Sci. (2019). 6(10): 10-19

\section{Samples}

A commercial formulations (as tablets) were used for the analysis of clopidogrel by using DPPA with DME electrode. The pharmaceutical formulations were subjected to the analytical procedures:

(1) Pharma Grel, F.C. Tablet, PHARMASYR, Damascus-SYRIA, each tablet contains: 75 $\mathrm{mg}$ of CLP (Exp. 08.2022).

(2) Plaraz, F.C. Tablet, AL-RAZI, Aleppo-SYRIA, each tablet contains: $75 \mathrm{mg}$ of CLP and (Exp. 04.2022).

(3) Norgrel Plus, F.C. Tablet, UNIPHARMA, Damascus-SYRIA, each tablet contains: 75 $\mathrm{mg}$ of CLP and $75 \mathrm{mg}$ ASPIRIN (Exp. 09.2020).

(4) Glopid, F.C. Tablet, EL-SAAD, AleppoSYRIA, each tablet contains: $75 \mathrm{mg}$ of CLP (Exp. 09.2022).

(5) Plofexine, F.C. Tablet, ASIA, Aleppo-SYRIA, each tablet contains: $75 \mathrm{mg}$ of CLP (Exp. 05.2020).

(6) Clotless, F.C. Tablet, APHAMEA, HamaSYRIA, each tablet contains: $75 \mathrm{mg}$ of CLP (Exp. 01.2021).

\section{Stock solutions of pharmaceutical formulations}

20 tablets of each studied pharmaceutical formulations were weighted accurately and mixed well. An amount of the powder equivalent to the weight of one tablet was solved in $25 \mathrm{~mL}$ methanol by using ultrasonic, filtered over a $100 \mathrm{~mL}$ flask and diluting to $100 \mathrm{~mL}$ with methanol; this solution contents 750 g. $\mathrm{mL}^{-1}$ of CLP for all studied pharmaceutical formulations.

\section{Working solutions of pharmaceuticals}

These solutions were prepared daily by diluting $100 \mu \mathrm{L}$ $(0.100 \mathrm{~mL})$ from stock solutions of pharmaceutical formulations into $25 \mathrm{~mL}$ volumetric flask, diluted with sodium acetate buffer $0.02 \mathrm{M}(\mathrm{pH} 8)$ to the mark (each solution contents $3.000 \mathrm{~g} \cdot \mathrm{mL}^{-1}$ of $\operatorname{CLP}\left(9.323 \times 10^{-6} \mathrm{M}\right)$.

\section{Analytical procedure}

$25 \mathrm{~mL}$ of working standard of clopidogrel or working solutions of pharmaceuticals were transferred to the cell. The solution was deoxygenated with $\mathrm{N}_{2}$ gas for $500 \mathrm{~s}$. The potential range was from -1050 to -1500 $\mathrm{mV}$ (versus $\mathrm{Ag} / \mathrm{AgCl}$ ) with differential pulse polarographic analysis using drop mercury electrode in the optimum conditions were applied.

\section{Results and Discussion}

\section{Differential pulse polarographic behavior}

The polarograms for concentration $0.50-30.0 \mu \mathrm{mol} . \mathrm{L}^{-1}$ (0.2100 - 12.5970 g.mL m $^{-1}$ of CLPB or $0.1609-9.6546$ g. $\mathrm{mL}^{-1}$ of CLP) in the optimal conditions using DPPA at DME were studied. The best definition of the analytical signals was found in sodium acetate $(0.02$ M) buffer $(\mathrm{pH} 8.0)$ at -1050 to $-1500 \mathrm{mV}$ (versus $\mathrm{Ag} / \mathrm{AgCl})$.

\section{The effect of supporting electrolytes (buffer)}

The electrochemical behavior of clopidogrel was studied in various supporting electrolytes such as \{Briton Robinson, di-sodium hydrogen phosphate dodecahydrate, sodium acetate-acetic acid (HAc$\mathrm{NaAc})$ and lithium perchlorate were studied $\}$ at $\mathrm{pH}(6.0$ - 10.0). The best definition of the analytical signals was found in sodium acetate buffer $(\mathrm{pH} 8.0)$ at concentration $0.02 \mathrm{M}$. The effect of supporting electrolytes (buffer) on the $I_{p}$ and $E_{p}$ was studied. The values of $E_{p}$ were $-1242,-1267,-1285$ and $-1287 \mathrm{mV}$ for the mentioned buffers, respectively, see Figure 1. The effect of the concentration of HAc- $\mathrm{NaAc}$ was tested over the $1,2,4,8,10,20,30,40,50,60,80$, and $100 \mathrm{mM}$. The DPPA at DME of $12 \mu \mathrm{M}$ of CLP with the varying concentrations of supporting electrolyte was studied. The values of $I_{p}$ increase with increasing concentration of supporting electrolyte of 4 to $10 \mathrm{mM}$, then become semi-fixed until concentration of supporting electrolyte $100 \mathrm{mM}$, while $E_{p}$ remains quasi-static. 
Int. J. Curr. Res. Chem. Pharm. Sci. (2019). 6(10): 10-19

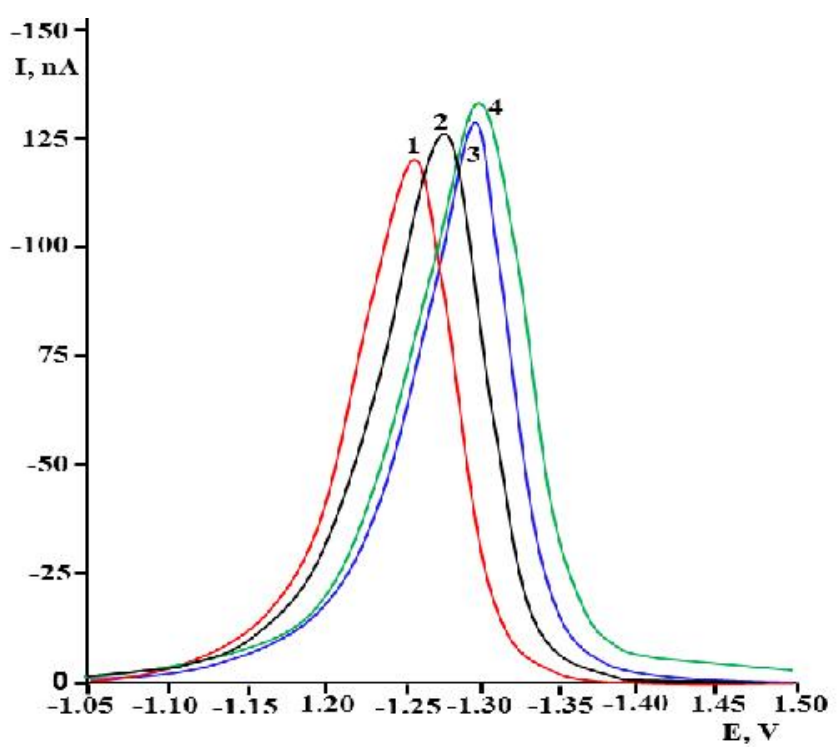

Fig.1:The effect of buffer solutions on polarograms $12 \mu \mathrm{M}$ of CLP using DPPA at DME buffers (0.02 M) at pH 8.0: 1Britton-Robinson, 2- $\mathrm{Na}_{2} \mathrm{HPO}_{4} \cdot 12 \mathrm{H}_{2} \mathrm{O}$, 3- $\mathrm{CH}_{3} \mathrm{COONa} \cdot 3 \mathrm{H}_{2} \mathrm{O}$, 4- $\mathrm{LiClO}_{4} \cdot 3 \mathrm{H}_{2} \mathrm{O}$ (Purge gas $\mathrm{N}_{2}$, purge time $500 \mathrm{~s}$, sweep rate $5 \mathrm{mV} / \mathrm{s}$, U. amplitude $-100 \mathrm{mV}$, t. meas $30 \mathrm{~ms}$, t. pulse $35 \mathrm{~ms}$, t. step $1.6 \mathrm{~s}$, U. step $8 \mathrm{mV}$, temperature $\left.25^{\circ} \pm 5^{\circ} \mathrm{C}\right)$.

\section{The effect of $\mathrm{pH}$}

The influence of $\mathrm{pH}$ from 6.0 to 10.0 using sodium acetate $(0.02 \mathrm{M})$ buffer on $I_{p}$ and $E_{p}$ was studied. The values of $I_{p}$ increase with increasing $\mathrm{pH}$ value of 6.0 to
8.0, then decrease until $\mathrm{pH} 9.0$ and finally decreasing slowly until $\mathrm{pH} 10$. While $\mathrm{E}_{\mathrm{p}}$ values are growing a positive value from $-1487 \mathrm{mV}$ (when $\mathrm{pH} 6.0$ ) to -1295 $\mathrm{mV}$ (when $\mathrm{pH} 7.0$ ) then become semi-fixed until $\mathrm{pH}$ 10, see Figures 2,3.

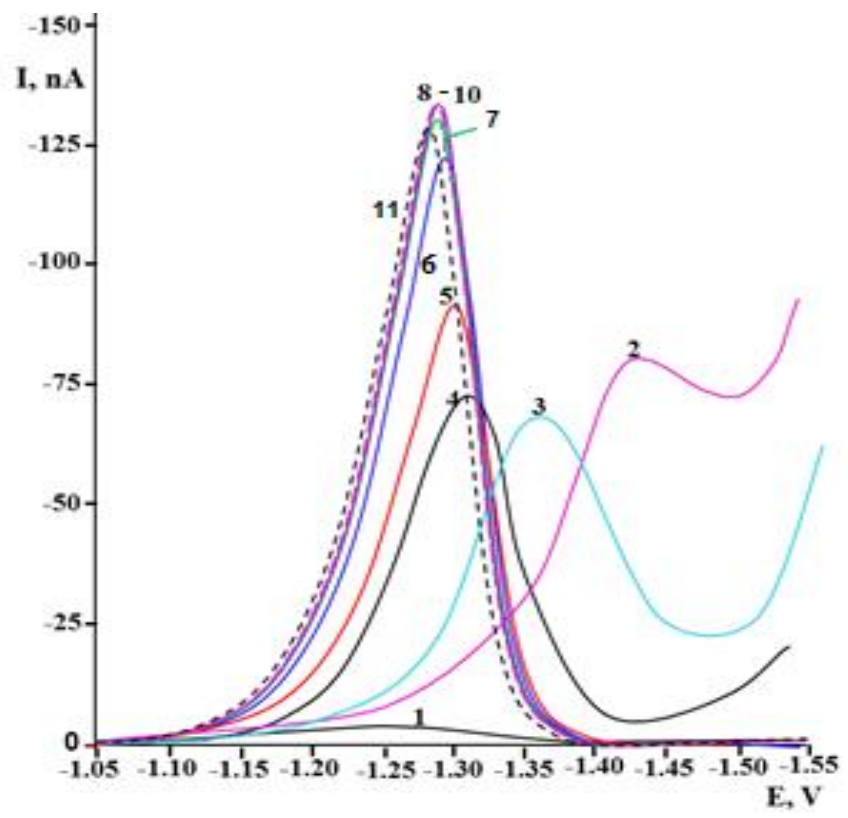

Fig.2: The effect of pH solution on polarograms of CLP $(12 \mu \mathrm{M})$ using DPPA at DME buffers (0.02 M) HAc-NaAc at $\mathrm{pH}:$ 1- Electrolyte $(\mathrm{pH}$ 8.00) , 2- 6.00, 3- 6.50, 4- 6.75, 5- 7.00, 6 -7.50, 7 - 7.75, 8- 8.00, 9- 8.50, 10- 9.00 and 1110.0 (purge gas $\mathrm{N}_{2}$, purge time $500 \mathrm{~s}$, sweep rate $5 \mathrm{mV} / \mathrm{s}$, U. amplitude $-100 \mathrm{mV}$, t. meas $30 \mathrm{~ms}$, t. pulse $35 \mathrm{~ms}$, t. step $1.6 \mathrm{~s}$, U. step $8 \mathrm{mV}$, temperature $25^{\circ} \pm 5^{\circ} \mathrm{C}$ ). 
Int. J. Curr. Res. Chem. Pharm. Sci. (2019). 6(10): 10-19
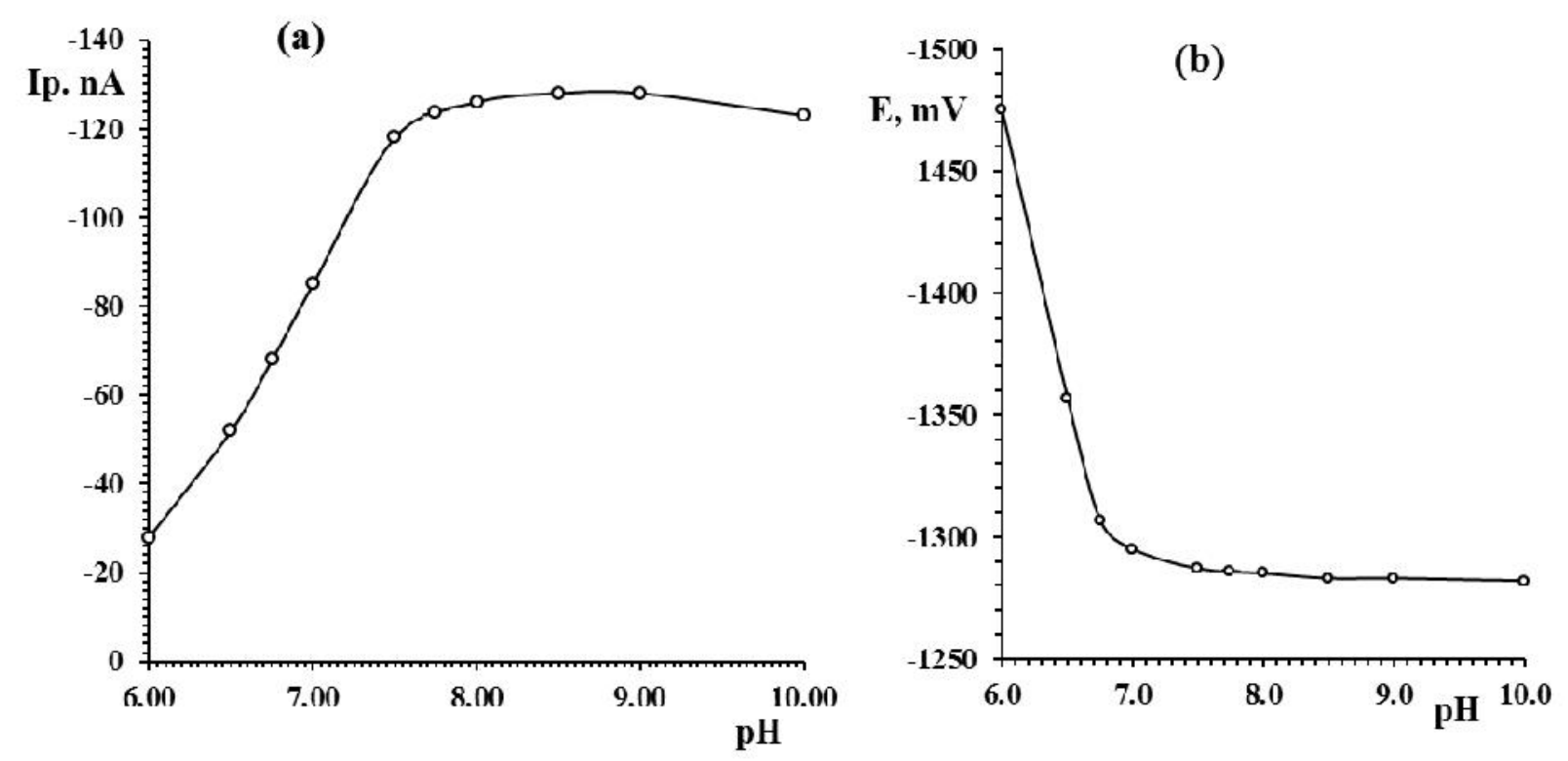

Fig.3: The effect of $\mathrm{pH}$ solution on $\mathrm{I}_{\mathrm{p}}(\mathrm{a})$ \& $\mathrm{E}_{\mathrm{p}}(\mathrm{b})$ of CLP $(12 \mu \mathrm{M})$ using DPPA at DME in buffer (0.02 M) HAc-NaAc (purge gas $\mathrm{N}_{2}$, purge time $500 \mathrm{~s}$, sweep rate $5 \mathrm{mV} / \mathrm{s}$, U. amplitude $-100 \mathrm{mV}$, t. meas $30 \mathrm{~ms}$, t. pulse $35 \mathrm{~ms}$, t. step 1.6 $\mathrm{s}$, U. step $8 \mathrm{mV}$, temperature $25^{\circ} \pm 5^{\circ} \mathrm{C}$ ).

\section{The effect of negative pulse amplitude (U.ampl)}

The effect of negative pulse amplitude (U.ampl) between -10 to $-100 \mathrm{mV}$ on Ip and Ep was studied. Ip linearly increases with increasing amplitude value until $-100 \mathrm{mV}$. While Ep stay semi-fixed. The value -100 $\mathrm{mV}$ was better than the others.

\section{The effect of time pulse (t.pulse)}

The effect of time pulse $(35,40,50,60,70,80,90$ and $100 \mathrm{~ms}$ ) on polarograms was as the follows: Ip decreases with increasing time pulse and Ep has become increasingly negative value $(-1275$ to -1310 $\mathrm{mV}$ ) with increasing t.pulse.

The peak was more symmetrical and Ip was the highest when the t.pulse value was $35 \mathrm{~ms}$.

\section{The effect of time interval for voltage step (t.step)}

Ip linearly increases with increasing t.step $(0.4,0.8$, 1.2, 1.6 and $1.8 \mathrm{~s}$ ), while Ep has become increasingly positive value $(-1310$ to $-1275 \mathrm{mV})$ with increasing t.step. The value of the preferred t.step was $1.6 \mathrm{~s}$.

\section{The effect of measurement time (t.meas)}

Ip increases with increasing t.meas. $(4,8,12,16,20$, 24, 28, 30, and $32 \mathrm{~ms}$ ), while Ep remains quasi-static. The value of the preferred t.meas. was $30 \mathrm{~ms}$.

\section{The effect of temperature and time}

The effect of temperature and time on the electrochemical behavior of CLP was studied at different values $\left(15-35^{\circ} \mathrm{C}\right.$ and $\left.5-60 \mathrm{~min}\right)$ by continuous monitoring of the Ip. It was found that, the value of Ip was not affected by temperature between 20 to $30^{\circ} \mathrm{C}$ (the temperature at $25 \pm 5^{\circ} \mathrm{C}$ was used). The effect of waiting time was determined at laboratory ambient temperature $\left(25 \pm 5^{\circ} \mathrm{C}\right)$. It was found that, the value of Ip was not affected by time between 5 to $60 \mathrm{~min}$.

The optimum parameters established for determination of CLP using DPPA on DME showed in Table 1.

\section{Calibration curves}

Calibration curves for the determination of clopidogrel using differential pulse polarographic analysis on drop mercury electrode with negative amplitude in sodium acetate $(0.02 \mathrm{M})$ buffer at $\mathrm{pH} 8.0$ were applied. One peak was observed in the range -1270 to $-1310 \mathrm{mV}$ (Ep). The peak current (Ip) was proportional to the concentration of CLP over the ranges 0.1609-9.6546 g. $\mathrm{mL}^{-1}\left(0.500-30.00 \mathrm{~mol} . \mathrm{L}^{-1}\right)$. The polarograms in the optimum conditions using DPPA at DME of CLP at different concentrations are showed in figure 4 . The regression equation and correlation coefficient $\left(R^{2}\right)$ were as the follows: $y=-31.9895 x-1.5536, R^{2}=0.9997$; while $y: I p, n A$ and $x: C$ of CLP, $g \cdot \mathrm{mL}^{-1}$. 
Int. J. Curr. Res. Chem. Pharm. Sci. (2019). 6(10): 10-19

Table 1: The optimum parameters established for determination of CLP using DPPA

\begin{tabular}{|c|c|}
\hline Parameters & Operating modes \\
\hline Working electrode & Dropping mercury electrode (DME) \\
Supporting electrolyte (buffer) & sodium acetate $0.02 \mathrm{M}$ \\
$\mathrm{pH}$ & 8.0 \\
Solvent clopidogrel & double distilled water \\
Purge gas & Pure $\mathrm{N}_{2}$ \\
Purge time & $500 \mathrm{~s}$ \\
Initial potential & $-1050 \mathrm{mV}$ \\
Final potential & $-1500 \mathrm{mV}$ \\
Scan rate & $5 \mathrm{mV} / \mathrm{s}$ \\
U.step & $8 \mathrm{mV}$ \\
t. meas & $30 \mathrm{~ms}$ \\
t. pulse & $-100 \mathrm{mV}$ \\
t. step & $35 \mathrm{~ms}$ \\
Value of pulse amplitude & $1.6 \mathrm{~s}$ \\
Temperature of solution & $25^{\circ} \pm 5^{\circ} \mathrm{C}$ \\
\hline
\end{tabular}

(b)

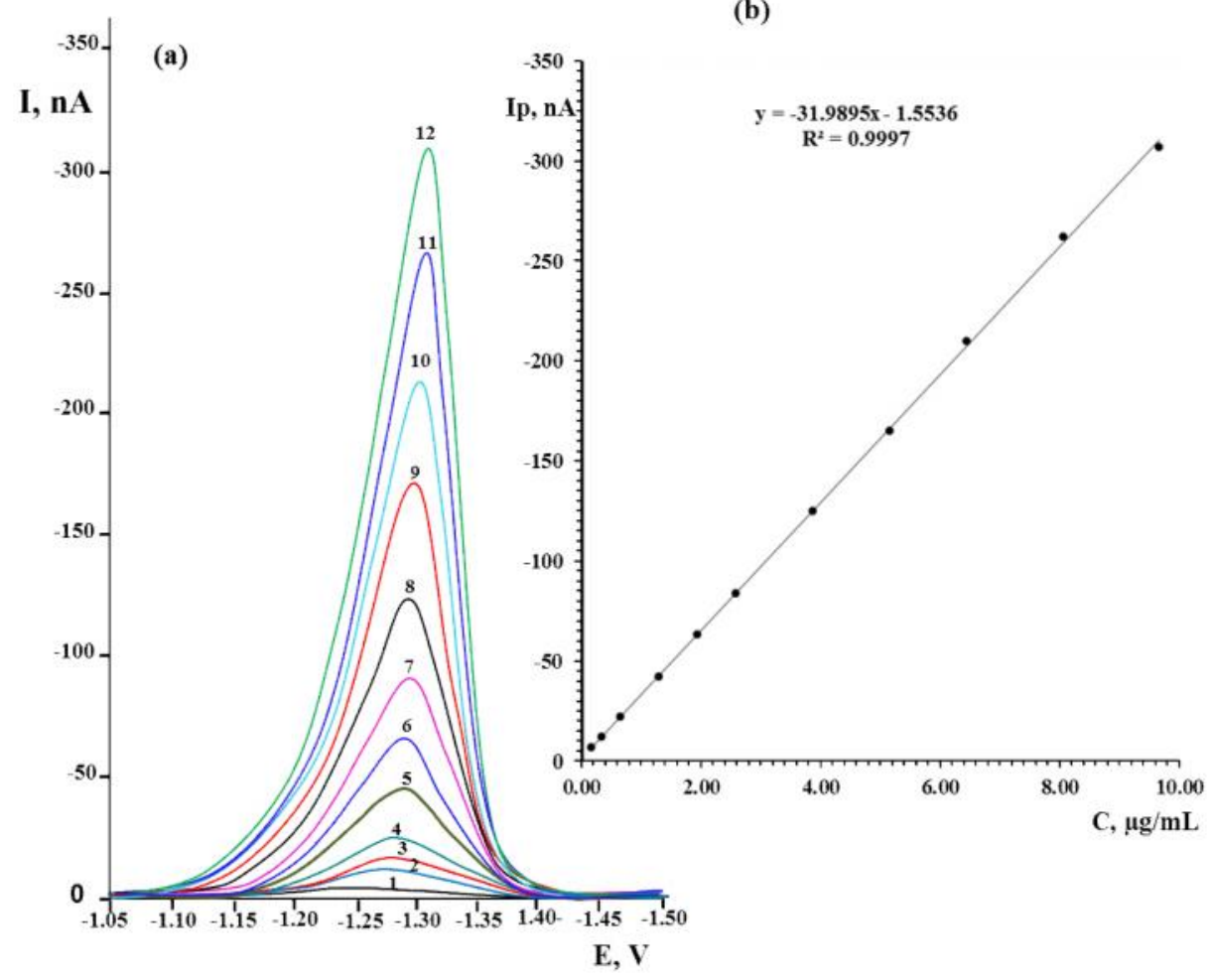

Fig.4: (a) The polarograms in the optimum conditions using DPPA on DME of CLP using DPPA at DME sodium acetate $0.02 \mathrm{M}$ buffer at concentrations: 1- electrolyte, 2- $0.1609,3-0.3218,4-0.6436,5-1.2873,6-1.9309$, 72.5746, 8- 3.8618, 9- 5.1491, 10- 6.4360, 11- 8.0460, 12- $9.6545 \mu \mathrm{g} \cdot \mathrm{mL}^{-1}$, (b) Calibration curves for the determination of CLP (purge gas $\mathrm{N}_{2}$, purge time $500 \mathrm{~s}$, sweep rate $5 \mathrm{mV} / \mathrm{s}$, U. amplitude $-100 \mathrm{mV}$, t. meas $30 \mathrm{~ms}$, t. pulse $35 \mathrm{~ms}$, t. step $1.6 \mathrm{~s}, \mathrm{U}$. step $8 \mathrm{mV}$, temperature $25^{\circ} \pm 5^{\circ} \mathrm{C}$ )

\section{Analytical results}

Determination of CLP using DPPA on DME in the optimum conditions using analytical curves, $I p=f\left(C_{C L P}\right)$, showed that the accuracy was ready over the ranges of CLP concentration between $0.500-30.00 \mu \mathrm{M}$
(0.2100 - $12.5970 \mu \mathrm{g} \cdot \mathrm{mL}^{-1}$ of CLB or $0.1609-9.6546$ $\mu \mathrm{g} \cdot \mathrm{mL}^{-1}$ of CLP). The percent relative standard deviation (RSD\%) not more than $2.9 \%$, see Table 2. Limit of detection (LOD) and limit of quantitation (LOQ) for the determination of CLP by this method were as the follows: 0.0160 and $0.0485 \mu \mathrm{g} \cdot \mathrm{mL}^{-1}$, respectively. 
Int. J. Curr. Res. Chem. Pharm. Sci. (2019). 6(10): 10-19

Table 2: Determination of clopidogrel using differential pulse polarographic analysis on DME with negative amplitude in sodium acetate $0.02 \mathrm{M}$ buffer $\mathrm{pH}$ 8.0.

\begin{tabular}{|c|c|c|c|c|c|}
\hline \multicolumn{2}{|c|}{ Taken $x_{i}$} & \multirow{2}{*}{$\begin{array}{l}\text { Found, } \\
\bar{x} \\
\mu \mathrm{g} \cdot \mathrm{mL}^{-1}\end{array}$} & \multirow{2}{*}{$\begin{array}{c}\text { SD, } \\
\mu \mathrm{g} \cdot \mathrm{mL}^{-1}\end{array}$} & \multirow{2}{*}{$\bar{x} \pm \frac{t \cdot S D}{\sqrt{n}}, \boldsymbol{\mu g} \cdot \mathrm{mL}^{-1}$} & \multirow{2}{*}{ RSD\% } \\
\hline$\mu \mathrm{M}$ & $\underset{\text { (CLp) }}{\mu \mathrm{g} \cdot \mathrm{mL}^{-1}}$ & & & & \\
\hline 0.500 & 0.1609 & 0.1671 & 0.00485 & $0.1671 \pm 0.00602$ & 2.9 \\
\hline 1.000 & 0.3218 & 0.3234 & 0.00906 & $0.3234 \pm 0.01125$ & 2.8 \\
\hline 2.000 & 0.6436 & 0.6392 & 0.01662 & $0.6392 \pm 0.02063$ & 2.6 \\
\hline 4.000 & 1.2873 & 1.2643 & 0.03161 & $1.2643 \pm 0.03924$ & 2.5 \\
\hline 6.000 & 1.9309 & 1.9208 & 0.04610 & $1.9208 \pm 0.05723$ & 2.4 \\
\hline 8.000 & 2.5746 & 2.5773 & 0.05928 & $2.5773 \pm 0.07360$ & 2.3 \\
\hline 12.00 & 3.8618 & 3.8590 & 0.08876 & $3.8590 \pm 0.11020$ & 2.3 \\
\hline 16.00 & 5.1491 & 5.1093 & 0.11240 & $5.1093 \pm 0.13954$ & 2.2 \\
\hline 20.00 & 6.4360 & 6.5160 & 0.13684 & $6.5160 \pm 0.16989$ & 2.1 \\
\hline 25.00 & 8.0460 & 8.1416 & 0.16283 & $8.1416 \pm 0.20215$ & 2.0 \\
\hline 30.00 & 9.6546 & 9.5483 & 0.16232 & $9.5483 \pm 0.20152$ & 1.7 \\
\hline
\end{tabular}

\section{Applications}

Many applications for the determination of clopidogrel in some Syrian pharmaceutical preparations using differential pulse polarographic analysis on drop mercury electrode with negative amplitude in sodium acetate $0.02 \mathrm{M}$ buffer $\mathrm{pH} 8.0$ according to the optimal conditions were proposed. The amount $(\mathrm{m})$ of CLP in one tablet was calculated from the following relationship: $m=h$. $m$ ', where: $m$ ' is the amount of CLP in tablet calculated according to the regression equation of calibration curve, $\mathrm{h}$ conversion factors are equal to 25 for all pharmaceuticals content $75 \mathrm{mg} / \mathrm{tab}$. The results of quantitative analysis for CLP in pharmaceutical preparations were summarized in Tables 3. The proposed method was simple, direct and successfully applied to the determination of CLP in pharmaceuticals without any interference from excipients. Average assay ranged between 99.3 to $102.0 \%$. The results obtained by this method agree well with the contents stated on the labels and were validated by HPLC method [14]. Therefore, the presented method can be recommended for routine analysis of CLP in pharmaceutical formulations

\section{Method validation}

The developed method for simultaneous estimation of CLP has been validated in accordance with the International Conference on Harmonization guidelines $(\mathrm{ICH})[12]$.

\section{Selectivity}

Several other components were examined under the conditions that had been optimized for clopidogrel determination. The results showed that aspirin did not interfere (The peak of aspirin did not appear within optimum conditions for clopidogrel determination). 
Int. J. Curr. Res. Chem. Pharm. Sci. (2019). 6(10): 10-19

Table 3: Determination of CLP in some Syrian pharmaceutical preparations using DPPA on DME with negative amplitude in sodium acetate $0.02 \mathrm{M}$ buffer $\mathrm{pH} 8.0$ according to the optimal condition.

\begin{tabular}{|c|c|c|c|c|c|}
\hline Commercial name & $\begin{array}{l}\text { Label Claim of } \\
\text { CLP, mg/tab. }\end{array}$ & $\begin{array}{c}{ }^{*} \text { Mean } \pm \text { SD } \\
\text { (as CLP), } \\
\text { mg/tab. }\end{array}$ & RSD\% & Assay \% & $\begin{array}{c}\text { * (Assay \%), } \\
\text { by HPLC } \\
{[14]}\end{array}$ \\
\hline $\begin{array}{c}\text { Pharma Gre, } \\
\text { F.C.Tablet } \\
\text { PHARMASYR, }\end{array}$ & 75.0 & 74.5 & 2.4 & 99.3 & 99.0 \\
\hline $\begin{array}{c}\text { Plaraz, F.C. Tablet } \\
\text { AL-RAZI }\end{array}$ & 75.0 & 76.0 & 2.3 & 101.3 & 100.9 \\
\hline $\begin{array}{l}\text { Norgrel Plus, F.C. } \\
\text { Tablet, UNIPHARMA }\end{array}$ & 75.0 & 75.5 & 2.5 & 100.7 & 101.0 \\
\hline $\begin{array}{c}\text { Glopid, F.C. Tablet, } \\
\text { EL-SAAD }\end{array}$ & 75.0 & 74.3 & 2.3 & 99.1 & 99.5 \\
\hline $\begin{array}{c}\text { Plofexine, F.C. Tablet, } \\
\text { ASIA, }\end{array}$ & 75.0 & 77.0 & 2.4 & 102.7 & 101.5 \\
\hline $\begin{array}{c}\text { Clotless, F.C. Tablet, } \\
\text { APHAMEA }\end{array}$ & 75.0 & 76.5 & 2.4 & 102.0 & 101.8 \\
\hline
\end{tabular}

Linearity

Several aliquots of standard stock solution of CLP were taken in different $25 \mathrm{~mL}$ volumetric flasks such that their final concentrations were $0.1609-9.6546$ g. $\mathrm{mL}^{-1}\left(0.500-30.00\right.$ mol. $\left.\mathrm{L}^{-1}\right)$ for CLP using DPPA at DME in sodium acetate $0.02 \mathrm{M}$ buffer at $\mathrm{pH} 8.0$. Linearity equation obtained for the mentioned range was $y=-31.9895 x-1.5536, \quad\left(R^{2}=0.9997\right)$, see figure 4 and table 2.

\section{Precision and Accuracy}

The precision and accuracy of proposed method were checked by recovery study by addition of standard drug solution to pre-analyzed sample solution at three different concentration levels $(80 \%, 100 \%$ and $120 \%)$ within the range of linearity for CLP (one table 75.00 $\mathrm{mg}$ ). The proposed method was validated statistically and through recovery studies. It was successfully applied for the determination of CLP in pure and dosage forms, table 4.

Table 4 : Results of recovery studies $(n=5)$.

\begin{tabular}{|l|c|c|c|c|c|}
\hline Level & $\begin{array}{c}\text { Quantity } \\
\text { present of CLP, } \\
\text { mg }\end{array}$ & $\begin{array}{c}\text { Quantity } \\
\text { added of } \\
\text { CLP, } \mathbf{~ m g}\end{array}$ & $\begin{array}{c}\text { The resulting } \\
\text { quantity of CLP, } \\
\text { mg }\end{array}$ & $\begin{array}{c}\text { Quality } \\
\text { determined } \\
\text { of CLP, }\end{array}$ & Recovery\% \\
\hline $80 \%$ & 75.00 & 60.00 & 135.00 & 136.35 & 101.0 \\
$100 \%$ & 75.00 & 75.00 & 150.00 & 149.85 & 99.9 \\
$120 \%$ & 75.00 & 90.00 & 165.00 & 165.83 & 100.5 \\
\hline
\end{tabular}

\section{Repeatability}

The repeatability was evaluated by performing 10 repeat measurements for $5.1491 \mu \mathrm{g} \cdot \mathrm{mL}^{-1}$ of CLP using the studied DPPA at DME sodium acetate $0.02 \mathrm{M}$ buffer $\mathrm{pH} 8.0$ under the optimum conditions. The found amount of CLP $(\bar{x} \pm S D)$ was $5.1287 \pm 0.110$ g.mL ${ }^{-1}$ and the percentage recovery was found to be $99.6 \pm$ 2.14 with RSD of 0.021 . These values indicate that the proposed method has high repeatability for CLP analysis.

\section{Sensitivity limit of detection [LOD] and limit of quantitation [LOQ]}

The sensitivity of the presented method was evaluated by determining the LOD and LOQ. The values of LOD

(C) 2019, IJCRCPS. All Rights Reserved and LOQ for CLP are 0.0160 and $0.0485 \mu \mathrm{g} \cdot \mathrm{mL}^{-1}$, respectively.

\section{Robustness}

The robustness of the method adopted is demonstrated by the constancy of the current peak $\left(I_{p}\right)$ with the deliberated minor change in the experimental parameters such as the change in the concentration of excipients, temperature $\left(25 \pm 5^{\circ} \mathrm{C}\right), \mathrm{pH}(8.0 \pm 0.20)$, $\mathbf{C}_{\text {electrolyte }}$ and reaction time. Table 5 is indicates that the robustness of the proposed methods. It was found that the robustness is good. 
Int. J. Curr. Res. Chem. Pharm. Sci. (2019). 6(10): 10-19

Table 5: Robustness of the proposed DPPA method at DME for determination of CLP.

\begin{tabular}{|l|c|c|}
\hline \multirow{2}{*}{$\begin{array}{c}\text { Experimental parameter } \\
\text { variation }\end{array}$} & \multicolumn{2}{|c|}{ Average recovery (\%)* } \\
\cline { 2 - 3 } Temperature & $\mathrm{C}_{\mathrm{CLP}}=1.2873 \mu \mathrm{g} \cdot \mathrm{mL}^{-1}$ & $\mathrm{C}_{\mathrm{CLP}}=5.1491 \mu \mathrm{g} \cdot \mathrm{mL}^{-1}$ \\
\hline $20^{\circ} \mathrm{C}$ & 99.6 & 99.8 \\
$25^{\circ} \mathrm{C}$ & 100.2 & 100.5 \\
$30^{\circ} \mathrm{C}$ & 101.1 & 100.7 \\
\hline $\mathbf{p H}$ & & \\
7.8 & 99.5 & 99.7 \\
8.2 & 100.2 & 99.9 \\
\hline $\mathbf{C}_{\text {electrolyte }}$ & & \\
0.015 mol/L & 100.5 & 99.5 \\
0.025 mol/L & 100.4 & 100.8 \\
\hline reaction time & & \\
10 min & 99.4 & 99.6 \\
30 min & 99.8 & 100.0 \\
60 min & 101.7 & 101.0 \\
\hline
\end{tabular}

\section{Specificity}

The specificity of the method was ascertained by analyzing standard CLP in presence of excipients. These findings prove that the suggested method is specific for determination of the investigated drugs without interference from the coformulated adjuvants.

\section{Conclusion}

Electrochemical behavior and DPPA of CLP (as CLPB) in pure form and in pharmaceutical preparations using DME with sodium acetate $0.02 \mathrm{M}$ buffer $\mathrm{pH} 8.0$ according to the optimal conditions was applied. One reduction peak was observed. Ip is linear over the range $0.1609-9.6545$ g. $\mathrm{mL}^{-1}(0.500-30.00$ mol. $L^{-1}$ ) of CLP. The percent relative standard deviation did not exceed $2.9 \%$ for the concentration 0.1609 g. $\mathrm{mL}^{-1}$ of CLP. Regression analysis showed a good correlation coefficient $\left(R^{2}=0.9997\right)$ between Ip and concentration over the mentioned range. The proposed method was successfully applied to the direct analysis of CLP in pharmaceutical formulations without any interference from excipients and with adequate accuracy and sensitivity without any preseparation such as extraction.

\section{References}

1. Budavari, S., 2011. "The Merck Index" 13th Ed. Merck \& Co. Inc. 856.

2. Henein, W., 2006. "Atlas 2 everything about drugs from A to Z". Nobar publisher. 282.

3. Alesci, J.P., Victorino, A., 2013. Clopidogrel: Pharmacology, Clinical Uses and Adverse Effects, Nova Science Pub Inc; UK.
4. Mostafa, A.M.A., $2016 . \quad$ "Clopidogrel personalization: Pharmacogenetics and pharmacometabonomics: A Review of the Litrature, LAP Lambert Academic Publishing.

5. Anderson J.L., Morrow D.A., 2017. "Acute myocardial infarction". The New England Journal of Medicine. 376(21):2053-2064.

6. Bin Ibrahim, S.F., Alarfaj, N.A., Aly, F.A., 2012. "Determination of clopidogrel bisulfate using ion-selective electrodes in bulk, pharmaceutical formulation and in biological fluids". J.American Science. 8:276-283.

7. Khorshid, A.F., 2014. "Determination of clopidogrel bisulphate in Plavix tablet and human biological fluids utilizing chemically modified carbon paste sensor". J. Bioproces Biotechniq. 4:1-9.

8. Dizavandi, Z.R., Aliakbar, A., Sheykhan, M., 2017. "Electrochemical determination of clopidogrel using $\mathrm{Bi}_{2} \mathrm{O}_{3}-\mathrm{Pp}-\mathrm{AP} / \mathrm{GCE}$ by differential pulse voltammetry in pharmaceutical productions". J. Electroanalytical Chemistry. 17:1-31.

9. Mohammadi, A., Barin, S.M., Naeemy, A., 2012. "Determination of clopidogrel using a graphite electrode modified by multi-walled carbon nanotube/ poly ortho aminophenol nanocomposite film". Research in Phamaceutical Science. 7:S645.

10. Nascimento, L.O., Scremin, J., Mattos, G.J., Gomes, A., Clausen, D.N., Sartori, E.R., 2019. "A Novel strategy for quantifying clopidogrel using square-wave voltammetry and a borondoped diamond film". Electroanalysis. 31:1-8. 
11. Mladenovic, A.R., Jovanovic, V.M., Petrovic, S.D., Mijin, D.Z., Drmanic S.Z., Ivic, M.L., 2013. "Determination of clopidogrel using square wave voltammetry at a gold electrode". J. Serb. Chem. Soc. 78:2131-2140.

12. Abdul Sattar, M.D., Rao, U.U., Priyanka, M., Kiran, K.B., Sudha, Ch.S., kumar, G.V., 2014. "Method development and validation for the estimation of clopidogrel in tablet dosage form by UV spectrophotometriv method". International Journal of Research and Novel Science. 1:171-175.

13. Mishra, P., Dolly, A., 2006. "Simultaneous determination of clopidogrel and aspirin in pharmaceutical dosage forms". J. Pharm. Sci. 68:365-368.

14. Shrivastava, P.K., Basniwal, P.K., Deepti, J., Shrivastava, S.K., 2008. "Concurrent estimation of clopidogrel bisulphate and aspirin in tablets by validated RP-HPLC Method". Indian J. Pharm. Sci. 70:667-669.

15. Sahoo, N.K., Sahu, M., Rao, P.S., Indira, J.N., Rani, S.N., Ghosh, G.K., 2014. "Validation of assay for bulk clopidogrel and for some tablet forms by reverse-phase high-performance liquid chromatography". J. Taibah Univ. Sci. $59: 1-6$.

\begin{tabular}{|c|l|}
\hline \multicolumn{2}{|c|}{ Access this Article in Online } \\
\hline Q & Website: \\
\hline & www.ijcrcps.com \\
\hline Quick Response Code & \\
\hline \multicolumn{2}{|c|}{ DOI: $10.22192 /$ ijcrcps.2019.06.10.002 } \\
\hline
\end{tabular}

How to cite this article:

Abdul Aziz Ramadan, Hasna Mandil, Nidal Ashram. (2019). Differential Pulse Polarographic Determination of Clopidogrel Bisulphate in Pure and Pharmaceutical Dosage Forms Using Dropping Mercury Electrode. Int. J. Curr. Res. Chem. Pharm. Sci. 6(10): 10-19.

DOI: http://dx.doi.org/10.22192/ijcrcps.2019.06.10.002 